\title{
Hyper-coherence and increased energy of gamma oscillations in patient with first onset schizophrenia and cerebral white matter damage
}

\author{
Kamil Jonak ${ }^{1,3}$ A,B,C,D,E,F, Paweł Krukow ${ }^{2,3}$ A,B,C,D,E,F, \\ Hanna Karakuła-Juchnowicz ${ }^{2,3}$ A,D,E,F
}

${ }^{1}$ Institute of Technological Systems of Information, Lublin University of Technology, Poland

2 Department of Clinical Neuropsychiatry, Medical University of Lublin, Poland

${ }^{3}$ Department of Psychiatry, Psychotherapy and Early Intervention, Medical University of Lublin, Poland

\begin{abstract}
Background: According to current knowledge, gamma frequency is closely related to the functioning of neural networks underlying the basic activity of the brain and mind. Disorders in mechanisms synchronizing brain activity observed in patients diagn osed with schizophrenia are at the roots of neurocognitive disorders and psychopathological symptoms of the disease. Synchronization mechanisms are also related to the structure and functional effectiveness of the white matter. So far, not many analysis has been conducted concerning changes in the image of high frequency in patients with comorbid schizophrenia and white matter damage. The aim of this research was to present specific features of gamma waves in subjects with different psychiatric diagnoses and condition of brain structure.

Methods: Quantitative analysis of an EEG record registered from a patient diagnosed with schizophrenia and comorbid white matter hyperintensities $(\mathrm{SCH}+\mathrm{WM})$, a patient with an identical diagnosis but without structural brain changes present in the MRI (SCH-WM) of a healthy control (HC). The range of gamma waves has been obtained by using analogue filters. In order to obtain precise analysis, gamma frequencies have been divided into three bands: $30-50 \mathrm{~Hz}, 50-70 \mathrm{~Hz}, 70-100 \mathrm{~Hz}$. Matching Pursuit algorithm has been used for signal analysis enabling assessing the changes in signal energy. Synchronization effectiveness of particular areas of the brain was measured with the aid of coherence value for selected pairs of electrodes.

Results: The electrophysiological signals recorded for the $\mathrm{SCH}+\mathrm{WM}$ patient showed the highest signal energy level identified for all the analyzed bands compared to the results obtained for the same pairs of electrodes of the other subjects. Coherence results revealed hipercompensation for the $\mathrm{SCH}+\mathrm{WM}$ patient and her level differed substantially compared to the results of the other subjects.

Conclusions: The coexistence of schizophrenia with white matter damage can significantly disturb parameters of neural activity with high frequencies. The paper discusses possible explanations for the obtained results.
\end{abstract}

Keywords schizophrenia, white matter, matching pursuit, coherence

\section{Streszczenie}

Wstęp: Zgodnie z obecną wiedzą częstotliwość gamma jest ściśle powiązana z działaniem sieci neuronowych leżących u podstaw podstawowej aktywności mózgu i umysłu. Zaburzenia mechanizmów synchronizacji aktywności mózgu obserwowane u pacjentów z rozpoznaniem schizofrenii, są podstawą zaburzeń neuropoznawczych i objawów psychopatologicznych choroby. Mechanizmy synchronizacją są także związane ze strukturą i efektywnością istoty białej mózgu. Dotąd przeprowadzono niewiele analiz zmian w obrazie wysokich częstotliwości, występujących u pacjentów ze schizofrenią i jednocześnie uszkodzeniami istoty białej. Celem pracy było zobrazowanie specyficznych cech fal gamma u osób z różnym rozpoznaniem psychiatrycznym i stanie struktury mózgu

Metody: Przeprowadzono analizę ilościową zapisu EEG zarejestrowanego dla pacjentki chorej na schizofrenię wraz ze stwierdzonym uszkodzeniem istoty białej mózgu (SCH+WM), pacjentki z tożsamym rozpoznaniem, ale bez zmian strukturalnych widocznych w MRI (SCH-WM) oraz osoby zdrowej (HC). Zakres fal gamma uzyskano przez zastosowanie filtrów analogowych, $\mathrm{w}$ celu szerszej analizy częstotliwości gamma podzielono na trzy pasma: 30-50Hz, 50-70Hz, 70-100Hz. Do analizy sygnału użyto algorytmu Matching Pursuit, dzięki któremu oceniono zmiany w energii sygnału. Do sprawdzenia efektywności synchronizacji poszczególnych obszarów mózgu użyto wskaźnika koherencji dla wybranych par elektrod.

Wyniki: Wyniki przeprowadzonych analiz wskazują, że w zapisie EEG pacjentki SCH+WM zidentyfikowano najwyższy poziom energii sygnału dla wszystkich analizowanych pasm w porównaniu do wyników uzyskanych dla tych samych par elektrod pozostałych dwóch osób. Wyniki koherencji wykazały hiperkompensacje u SCH+WM a jej poziom różnił się zasadniczo od wyników pozostałych osób.

Wnioski: Współwystępowanie schizofrenii i uszkodzeń istoty białej może istotnie zakłócać parametry aktywności neuronalnej o wysokich częstotliwościach. Poddano dyskusji propozycje wyjaśnień uzyskanych wyników.

Słowa kluczowe schizofrenia, istota biała, matching pursuit, koherencja

\section{Introduction}

Since Hans Berger first measured the brain activity of humans in 1924, using the analog electroencephalo- gram (EEG), there is observed constant increase in knowledge regarding bioelectrical activity of the human brain, and this development is associated with the intro- 
duction of digital EEG recording and computational methods of electrophysiological signal analysis. One aspect of bioelectrical neurons activity are the fastest oscillations with a frequency higher than $40 \mathrm{~Hz}$, called gamma waves $(\gamma)$. This interest is related to the finding that the gamma frequency is closely related to the functioning of neural networks underlying the basic activity of the brain and mind, and that gamma waves are involved in the integration and synchronization of distant neural structures, enabling the operation of complex cognitive processes, and taking part in the sense of the unity of consciousness $[1,2,3]$. The research focused on the analysis of the gamma frequency, also allow to assess certain parameters of the brains biochemistry, what is possible because known neural structures generating gamma rhythm, are also related to the specific type of neurotransmitters, associated with the balance between the excitatory and inhibitory processes regulating neuronal activity. Ensembles of fast-spiking inhibitory interneurons, included in the GABAergic system, are known to be crucial, with their activity being both necessary and sufficient to generate discussed frequency [4]. GABA (gamma-aminobutyric acid) is an inhibitory neurotransmiter that is widely distributed in the whole brain. Mentioned balance of neuronal activity is on the other hand associated with glutamatergic transmission, having an excitatory effect, therefore any substantial abnormalities in gamma frequency might be associated with significant impairment of brain activity and highly probable mental disorders [5].

One of neuropsychiatric disorders in which there were identified abnormal EEG characteristics, including the activity of high frequencies is schizophrenia. The disease is associated with the occurrence of multiple cognitive functions impairments (e.g. attention, problem solving, memory and cognitive speed), which significantly hinder the daily functioning of patients, and sometimes, with comorbid psychopathological symptoms make independent existence impossible. The disease is still not curable, despite the progress in the development of pharmacotherapy, and the fact that morbidity continuously is about 5 cases per 1,000 people, makes the effects of the disease a significant social and economic concern [6].

In patients with schizophrenia of varying duration of the disease, gamma oscillations evoked in the auditory cortex by external stimuli are reduced in power (amplitude) compared with healthy individuals. Decrease in gamma power were also found in patients with schizophrenia during a visual stimulation that necessitates perceptual organization and provide the feeling of objects unity $[7,8]$. Authors also showed that patients with schizophrenia are characterized by weaker parameters of the high frequencies synchronization within one hemisphere in response to the presentation of the stimulus, which modality is consistent with the functional specifics of the given brain hemisphere, which seems to confirm important role of gamma frequency in synchronizing distant brain structures [9]. Majority of the studies are focused on association between anomalous features of evoked gamma oscillations in schizophrenia and disturbed cognitive functions, and in most of the papers the existence of such a relationship was confirmed, although it should be marked, that those studies include analysis of gamma activity as a response to external stimuli or an experimental tasks measuring various cognitive processes $[10,11]$. Less research are available on the resting state gamma frequency in patients with schizophrenia, and those resting state records are often analyzed in clinical practice. In several such papers [12,13,14], obtained results show that resting state spectral power in gamma frequencies $(30-100 \mathrm{~Hz})$ bands across many brain regions was increased in the schizophrenia group compared to healthy controls, what is an inverse result comparing with studies using evoked gamma oscillations. Unfortunately, those data regarding spontaneous gamma frequencies are not fully explained so far, while taking into account the main function of gamma oscillations and power, it seems likely that they reflect an impaired synchronization of various brain areas activity, both during information processing and in the resting condition.

This raises the question as to what characteristics will have various parameters of frequency and power in gamma band in patients in which there are additional white matter damage, and thus a kind of "wiring" of the brain impairments, which provides a combination of anatomical connections between distant neural structures necessary for the proper operation of the mind. Having regard to the foregoing data one can hypothesize that: overactive gamma power and frequency in resting EEG reflects a pathological hypersynchronization of cortex as a reaction to the dysfunctional subcortical connections running through the white matter fibers. If this hypothesis will be confirmed, it seems more likely that that increase in the power gamma in resting EEG records of patients with schizophrenia is associated with damage to the subcortical areas ensuring the correct anatomical connections for cooperation of distant brain structures.

\section{Subjects and Methods \\ Subjects}

Three participants for the experiment were chosen, two from group of clinical patients. The first one $\mathrm{SCH}-$ WM) was a woman aged 25, with clinical diagnosed schizophrenia. Patient had MRI examination, but visualized brain structures does not show any structural abnormalities. Also in the EEG study there were no disorders during steady state record with closed eyes. During therapy patient took Olanzapine in $20 \mathrm{mg}$ doses per day. 
The second one patient ( $\mathrm{SCH}+\mathrm{WM})$ was a woman aged 23, also with clinical diagnosed schizophrenia, but in this case MRI examination show structural abnormities (Fig.1). Radiologist define result of the examination as "presence more than seven focuses of white matter hyperintensities seen on PD and T2-weighted MR including fluid attenuated inversion recovery sequence imaging present in both hemispheres, size up to $8 \mathrm{~mm}$. Changes are localized both in deep white matter and periventricular. One of them (on the border of the left frontal and parietal lobes, with a diameter of 3 $\mathrm{mm}$ ) shows a strengthening intensity after intravenous administration of contrast". EEG study also show abnormalities in frontotemporal, mainly theta-delta group of waves.

The healthy control was a woman aged 24, with clear MRI and EEG examinations.

\section{Recording}

Data was recorded from 22 channels, using Ag/Agcl electrodes mounted in 10-20 system. Sampling frequency was $256 \mathrm{~Hz}$. During the recording active $50-60 \mathrm{~Hz}$ stopband filters and $0.1 \mathrm{~Hz}$ high-pass with $200 \mathrm{~Hz}$ low-pass filters were applied. Electrode impedance was below $10 \mathrm{kOhm}$. Signal was recorded by ELMIKO Digit Track and converted to EDF data format. During the 20 minute long EEG procedure subjects has been subjected to photostimulation and hyperventilation. For most of the time patients eyes were closed, they open it only for technician orders.

\section{Data preprocessing}

The first thing in EEG data processing was to choose artefact-free 30s time section for every subject. For better examination of fast brain waves and to minimized impact of current artifacts gamma band was split into three bands $30-50 \mathrm{~Hz}, 50-70 \mathrm{~Hz}, 70-100 \mathrm{~Hz}$. To get expected frequencies, raw signal was filtered with analog filters designed in MATLAB.

The first two bands $30-50 \mathrm{~Hz}$ and $50-70 \mathrm{~Hz}$ where filtered by passband Chebyshev I filter with stopband attenuation $25 \mathrm{db}$. Chebyshev has been chosen because, the falling edge of the filter in this case is the steepest with the selected parameters [15]. Filter has been designed based on:

$$
\left|H_{C, N}\left(j\left(\omega / \omega_{0}\right)\right)\right|=\frac{1}{\sqrt{1+\varepsilon^{2} C_{N}^{2}\left(\omega / \omega_{0}\right)}}
$$

where: $\quad \varepsilon$ - is the ripple factor

$\omega_{0}$ - is the cutoff frequency

$C_{N}\left(\omega / \omega_{0}\right)$ - is the Chebyshev polynomial of the $n$-th order
Fig 2. White matter hyperintensities in the frontal lobe (a.) and parietal area (b.) in SCH+WM patient.

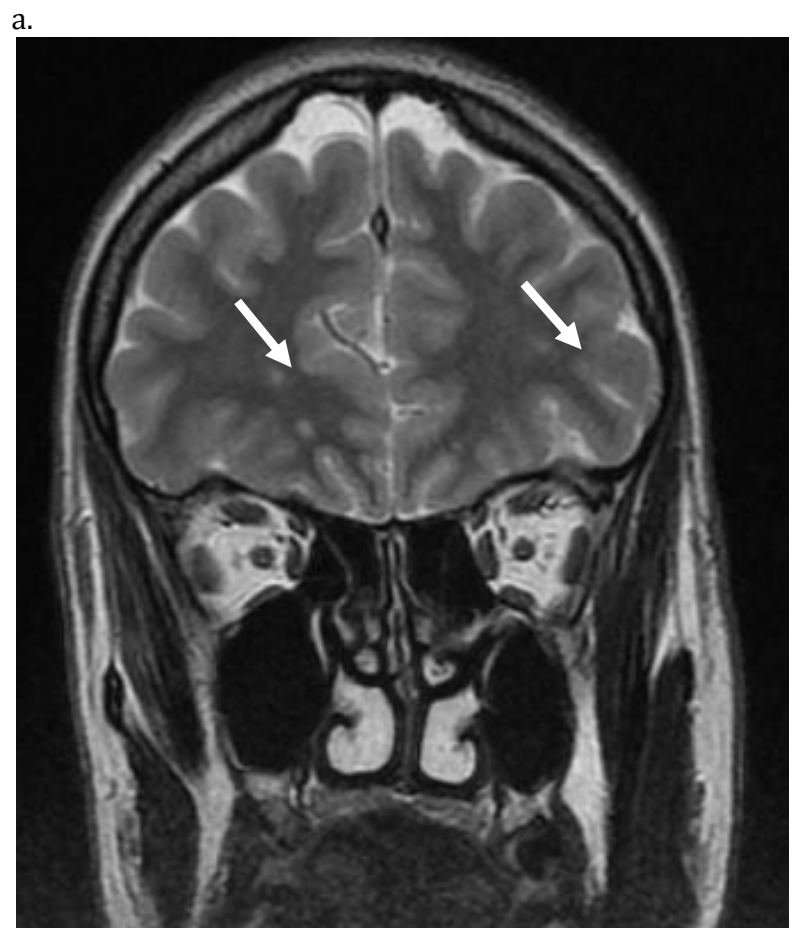

b.

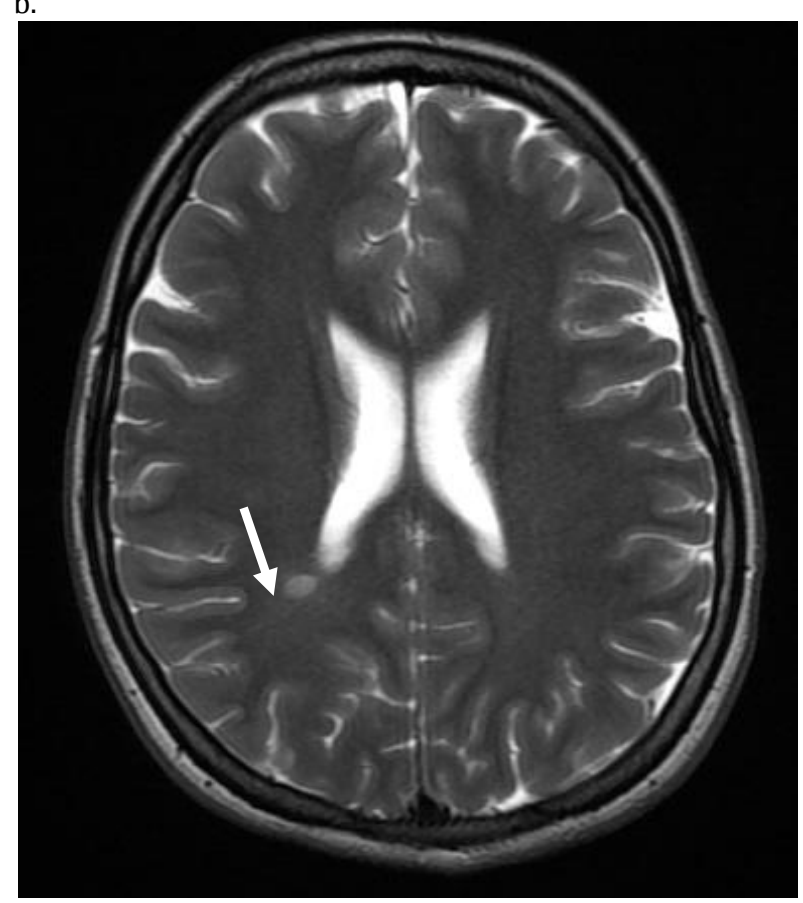

The last one frequency band was $70-100 \mathrm{~Hz}$ and in this case stopband attenuation was set on $20 \mathrm{~dB}$. Passband ripple was $3 \mathrm{~dB}$ for both filters and ripple factor $\varepsilon$ value was determined by:

$$
\varepsilon=\sqrt{10^{A_{\text {pass }} / 10}-1}
$$

where: $A_{\text {pass }}$ - is maximum passband attenuation 


\section{Signal analysis}

\section{Coherence}

Coherence between individual pairs of signals was the first step in signal analysis. In many papers researchers point disconnections between different brain areas as one of most common brain dysfunctions in schizophrenia [16]. In order to provide such abnormalities, it has been chosen four inside-hemispheric pairs F7-T5, F8-T6, F3-P3, F4-P4 and four inter-hemisphere pairs F3-F4, F7-F8, T3-T4, P3-P4. To show coherence changes for every single frequency point, not only average value, coherences was calculated in MATLAB by magnitude square coherence (mscohere) function described as [17]:

$$
K_{x y}(\omega)=\frac{\left|S_{x y}(\omega)\right|^{2}}{S_{x x}(\omega) S_{y y}(\omega)}
$$

where: $S_{x x}(\omega) S_{y y}(\omega)$ - are the power spectrum densities of two signals $S_{x y}(\omega)$ - is cross power spectral density of two signals Cross power spectrum density is defined as:

$$
S_{x y}(\omega)=\sum_{m=-\infty}^{\infty} R_{x y}(m) e^{-j a m}
$$

where: $R_{x y}(m)$ - is a cross-correlation sequence

\section{Matching Pursuit}

Last signal analysis process was to apply Matching Pursuit (MP) algorithm [18], for time-frequency signal energy calculation. MP is defined as iterative sequence that can decompose signal into linear combinations of functions $g_{n}$ called "atom". Atom functions, usually called as Gabor atoms are the best compromise between time and frequency resolution, set of Gabor atoms create timefrequency dictionary [19]. At the beginning MP create first iteration and chose which $g_{0}$ atom from dictionary will be best description of tested signal. For each analyzed signal frequency band Gabor dictionary was limited to 100 atoms, which allows to see precisely for what frequencies signal energy density $E s(t, \omega)$ was highest. Signal energy density was calculated by:

$$
\int_{-\infty}^{+\infty} \int_{-\infty}^{+\infty} E s(t, \omega) d t d \omega=\|s\|^{2}
$$

In signal processing theory the energy $E_{s}$ is not strictly the same value as notion of energy in other sciences. There is possibility to connect those two values by using:

$$
E=\frac{E_{s}}{Z}=\frac{1}{Z} \int_{-\infty}^{\infty}|x(t)|^{2} d t
$$

where: $\mathrm{Z}$ - represents the magnitude of the load driven by the signal

If we consider to apply (5) for electrical circuits, $x(t)$ will be electrical potential in volts, so the $\mathrm{Z}$ value will represent the impedance of the transmission line.

\section{Results}

\section{Coherence}

Results of mscohere algorithm will be present as a distribution of values for a particular frequency points (Figure 2) and as an average values for whole band presented in Table 1.

Results of coherence-frequency distribution for single points are presented on (Figure 2) three subplots. Each subplot show different frequency band, a) represent $30-50 \mathrm{~Hz}, \mathrm{~b}$ ) for $50-70 \mathrm{~Hz}$ and c) shows $70-100 \mathrm{~Hz}$ band. Subplots are divided into two rows of small plots, every upper one plots series shows intrahemispheric electrode pairs and the lowers show interhemispheric pairs. Results for every subject have different line styles: $\mathrm{SCH}+\mathrm{WM}$ solid line, SCH-WM - dotted line, HC - dash-dot line. At first subplot (a) one can see that in every pair of electrodes most coherent brain signals have subject $\mathrm{SCH}+\mathrm{WM}$. Most discoherent signals have patient SCH-WM which can be sign of neural disconnections. Red curve representing $\mathrm{HC}$, mostly oscillates between $\mathrm{SCH}+\mathrm{WM}$ curve and $\mathrm{SCH}-$ WM, only for coherence of T3-T4 signals SCH-WM have bigger coherence value. Second subplot (b) shows coherence of signals located in $50-70 \mathrm{~Hz}$ frequency band. In this plot series again coherence distributions of subject $\mathrm{SCH}+\mathrm{WM}$ are the most dominant. The lowest coherence value in this frequency band have subject SCH-WM which also may indicate on desynchronization of some brain areas. HC participants values are located in upper parts of plots but still for this band coherence values are lower than for SCH+WM. Last subplot (c) shows that also for 70$100 \mathrm{~Hz}$ band $\mathrm{SCH}+\mathrm{WM}$ coherence values are the highest. Third plot sequence shows also smaller disproportion of coherence values between $\mathrm{HC}$ and $\mathrm{SCH}+\mathrm{WM}$. Also for 70$100 \mathrm{~Hz}$ band WM-WM have lowest coherence value but coherence disproportions in that frequency band are lower between whole group than for subplots $a$ and $b$.

Additional way to show coherence fluctuations is described in Table 1, with averaged coherence values. Table was split horizontally into three rows, each one shows different frequency band, first $30-50 \mathrm{~Hz}$, second 50 $70 \mathrm{~Hz}$ and the third one is $70-100 \mathrm{~Hz}$. Vertically table has two main verses which divide intrahemispheric and interhemispheric electrode pairs and third verse show mean of intra- and interhemispheric coherences. 
Fig.2 Three subplots (a,b,c) contain coherence distribution curves for three frequency bands $30-50 \mathrm{~Hz}, 50-70 \mathrm{~Hz}$ and 70 $100 \mathrm{~Hz}$. Every subplot is split into two rows where upper row contains coherence distributions for intrahemispheric electrode pairs and lower for interhemispheric pairs. Coherence distribution line styles are: solid line for $\mathrm{SCH}+\mathrm{WM}$, dashdot line for HC and dotted line for SCH-WM

a)
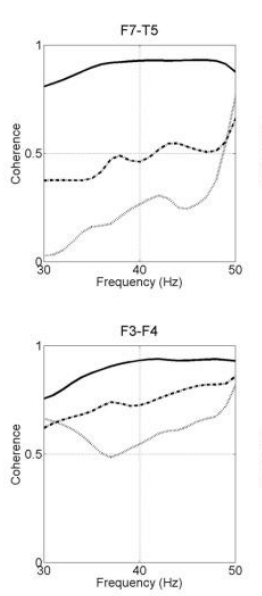

b)
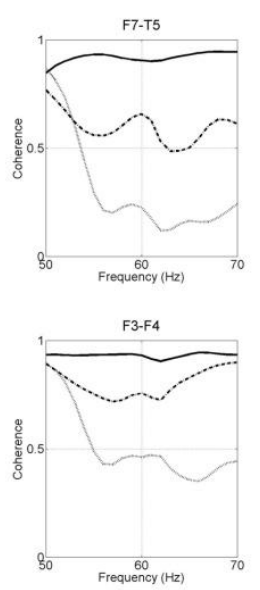

c)
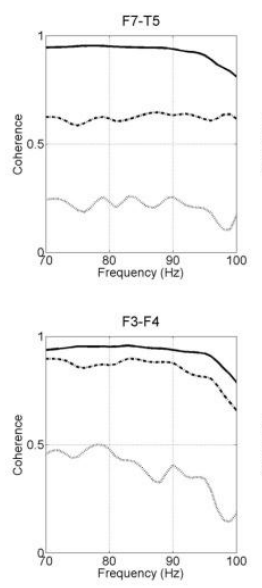
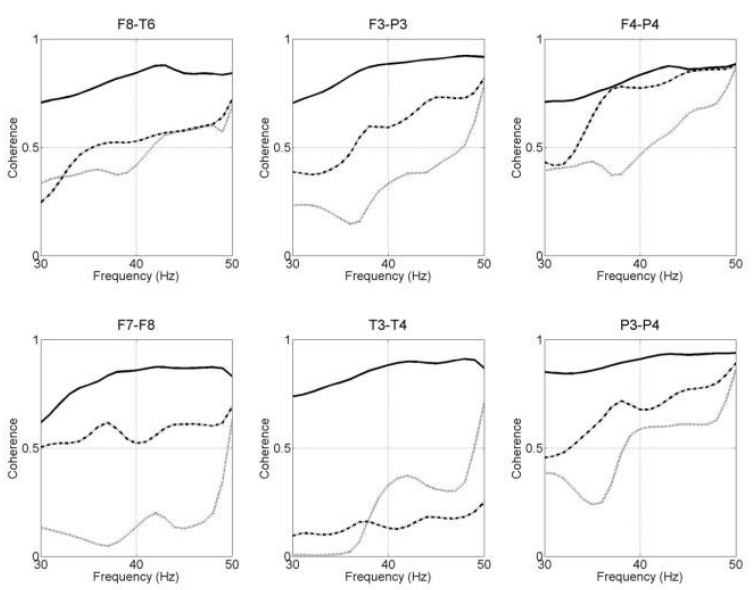

$50-70 \mathrm{~Hz}$
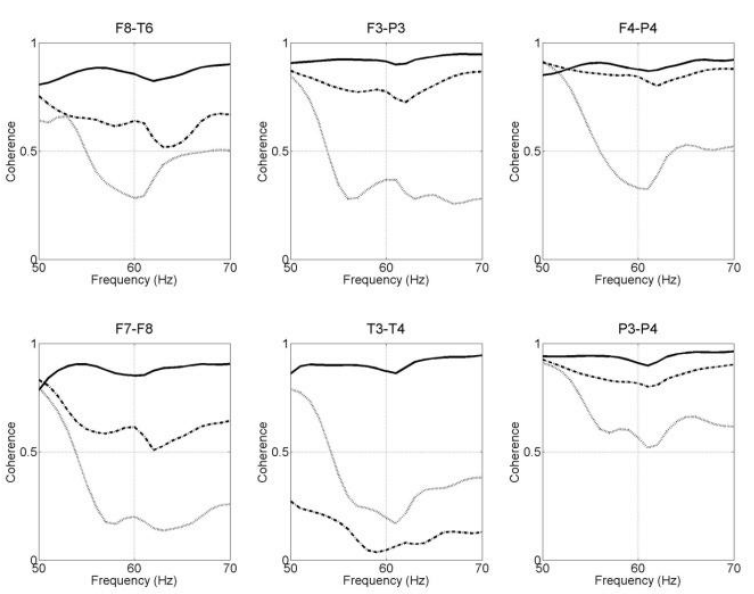

70-100Hz
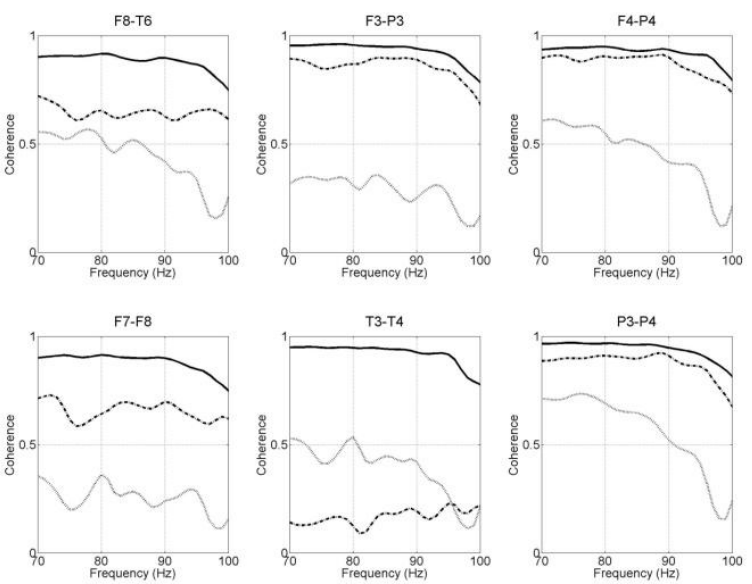
Tab.1 The table contains average coherence values for three frequency bands $30-50 \mathrm{~Hz}, 50-70 \mathrm{~Hz}$ and $70-100 \mathrm{~Hz}$, for each subject individual. Each electrode pairs were split for two groups intrahemispheric and interhemispheric. Third row placed on the bottom of the table shows mean of intra and interhemispheric average coherences values

\begin{tabular}{|c|c|c|c|c|c|c|c|c|c|c|}
\hline & \multicolumn{3}{|c|}{$30-50 \mathrm{~Hz}$} & \multicolumn{3}{|c|}{$50-70 \mathrm{~Hz}$} & \multicolumn{3}{|c|}{$70-100 \mathrm{~Hz}$} \\
\hline & & $\mathrm{HC}$ & SCH-WM & $\mathrm{SCH}+\mathrm{WM}$ & $\mathrm{HC}$ & SCH-WM & $\mathrm{SCH}+\mathrm{WM}$ & $\mathrm{HC}$ & SCH-WM & $\mathrm{SCH}+\mathrm{WM}$ \\
\hline \multirow{5}{*}{$\begin{array}{l}\text { Intrahe- } \\
\text { mispheric } \\
\text { pairs }\end{array}$} & F7 - T5 & 0.47 & 0.19 & 0.94 & 0.63 & 0.33 & 0.96 & 0.64 & 0.22 & 0.96 \\
\hline & F8 - T6 & 0.50 & 0.49 & 0.84 & 0.66 & 0.49 & 0.91 & 0.67 & 0.46 & 0.91 \\
\hline & F3-P3 & 0.58 & 0.33 & 0.88 & 0.84 & 0.42 & 0.97 & 0.89 & 0.29 & 0.96 \\
\hline & $\mathrm{F} 4-\mathrm{P} 4$ & 0.72 & 0.54 & 0.83 & 0.9 & 0.57 & 0.93 & 0.9 & 0.48 & 0.95 \\
\hline & M & 0.56 & 0.38 & 0.87 & 0.49 & 0.45 & 0.94 & 0.77 & 0.36 & 0.945 \\
\hline \multirow{5}{*}{$\begin{array}{l}\text { Interhe- } \\
\text { mispheric } \\
\text { pairs }\end{array}$} & F3-F4 & 0.76 & 0.62 & 0.92 & 0.84 & 0.53 & 0.98 & 0.88 & 0.4 & 0.96 \\
\hline & F7 - F8 & 0.59 & 0.13 & 0.84 & 0.65 & 0.32 & 0.92 & 0.68 & 0.26 & 0.91 \\
\hline & $\mathrm{T} 3-\mathrm{T} 4$ & 0.14 & 0.18 & 0.88 & 0.13 & 0.41 & 0.95 & 0.17 & 0.41 & 0.95 \\
\hline & P3 - P4 & 0.68 & 0.49 & 0.93 & 0.9 & 0.71 & 0.98 & 0.91 & 0.59 & 0.97 \\
\hline & $\mathbf{M}$ & 0.54 & 0.37 & 0.89 & 0.63 & 0.49 & 0.95 & 0.66 & 0.41 & 0.95 \\
\hline \multicolumn{2}{|c|}{$\begin{array}{l}\text { Mean of intra- and } \\
\text { interhemispheric } \\
\text { coherences }\end{array}$} & 0.55 & 0.375 & 0.88 & 0.57 & 0.47 & 0.945 & 0.71 & 0.385 & 0.95 \\
\hline
\end{tabular}

Tab.2 The table contains energy values for single EEG channels obtained by MP algorithm. Three main rows for three subjects (HC, SCH-WM, SCH+WM) shows energy values for three frequency bands $30-50 \mathrm{~Hz}, 50-70 \mathrm{~Hz}$ and $70-100 \mathrm{~Hz}$

\begin{tabular}{|c|c|c|c|c|c|c|c|c|c|}
\hline & \multicolumn{3}{|c|}{$\mathrm{HC}$} & \multicolumn{3}{c|}{$\mathrm{SCH}-\mathrm{WM}$} & \multicolumn{3}{c|}{ SCH + WM } \\
\cline { 2 - 11 } & $30-50 \mathrm{~Hz}$ & $50-70 \mathrm{~Hz}$ & $70-100 \mathrm{~Hz}$ & $30-50 \mathrm{~Hz}$ & $50-70 \mathrm{~Hz}$ & $70-100 \mathrm{~Hz}$ & $30-50 \mathrm{~Hz}$ & $50-70 \mathrm{~Hz}$ & $70-100 \mathrm{~Hz}$ \\
\hline F3 & 804 & 126 & 185 & 612 & 56 & 80 & 1403 & 183 & 260 \\
\hline F4 & 771 & 127 & 189 & 668 & 56 & 73 & 1384 & 182 & 255 \\
\hline P3 & 911 & 125 & 188 & 617 & 53 & 68 & 1351 & 182 & 261 \\
\hline P4 & 863 & 137 & 201 & 685 & 55 & 72 & 1289 & 173 & 243 \\
\hline F7 & 763 & 138 & 198 & 472 & 54 & 71 & 1415 & 186 & 263 \\
\hline F8 & 698 & 132 & 200 & 602 & 61 & 80 & 1276 & 172 & 242 \\
\hline T3 & 904 & 170 & 248 & 448 & 49 & 64 & 1364 & 181 & 258 \\
\hline T4 & 1682 & 329 & 471 & 606 & 53 & 72 & 1162 & 156 & 218 \\
\hline T5 & 870 & 134 & 191 & 469 & 57 & 71 & 1347 & 180 & 256 \\
\hline T6 & 834 & 151 & 232 & 605 & 57 & 73 & 1154 & 160 & 223 \\
\hline
\end{tabular}

Analyzing the first frequency band $(30-50 \mathrm{~Hz})$ we can see that biggest values for coherence have $\mathrm{SCH}+\mathrm{WM}$, values for $\mathrm{HC}$ are evidently less than for $\mathrm{SCH}+\mathrm{WM}$. Compering $\mathrm{SCH}+\mathrm{WM}$ with $\mathrm{SCH}-\mathrm{WM}$ differences are even twice as high for both intrahemispheric and interhemispheric pairs. In second frequency band $(50-70 \mathrm{~Hz})$ differences between $\mathrm{HC}$ and $\mathrm{SCH}+\mathrm{WM}$ are still high and $\mathrm{SCH}+\mathrm{WM}$ have bigger coherence values for second band than for the first one. Subject SCH-WM in this frequency range have higher coherence values than in earlier analyses, but those indexes are still the lowest in both intrahemispheric and interhemispheric pairs, and lowest among other subjects. Last frequency band is characterized by high coherence average values for HC subject, and in this case again $\mathrm{SCH}+\mathrm{WM}$ has the biggest average coherence values. Strongest differences in the third band are for SCH-WM subject where the values of coherence are lower than in $50-70 \mathrm{~Hz}$ band when for both $\mathrm{HC}$ and $\mathrm{SCH}+\mathrm{WM}$ the values of coherence are rising.

Summarizing the coherence results, in all analyzed cases, $\mathrm{SCH}+\mathrm{WM}$ subject had abnormally high coherence values for both intrahemispheric and interhemispheric pairs. Distribution of coherence values presented on sub- plots were also highest for $\mathrm{SCH}+\mathrm{WM}$. Lowest coherence results had subject $\mathrm{SCH}-\mathrm{WM}$, the indexes for this subject where even two times lower than for $\mathrm{SCH}+\mathrm{WM}$. Coherence results for $\mathrm{HC}$ subject where oscillating around 0.5 0.6 average scores and the coherence distribution on plots was also concentrated in the middle of scale value.

\section{Matching Pursuit}

Matching pursuit analysis was implemented to show energy features of the signal, which can inform about brain activity abnormalities. Results of MP algorithm were energy indicators for each EEG channel separately (Table 2). For better evaluation, the table was split into three main rows, every one represent energy results for different subjects, for three different frequency bands. The first row shows differences of energy level for $\mathrm{HC}$ subject, the second one for $\mathrm{SCH}-\mathrm{WM}$ subject and the third one for $\mathrm{SCH}+\mathrm{WM}$ subject. It can be seen that energy values for every subject are highest in $30-50 \mathrm{~Hz}$ frequency band and lowest for 50 $70 \mathrm{~Hz}$ frequency band. Most important differences can be seen when energy scores for same bands but different subjects are compare. For first band $(30-50 \mathrm{~Hz})$ energy indexes are the highest for subject $\mathrm{SCH}+\mathrm{WM}$ which values are signifi- 
cantly bigger than for HC and almost two times higher as in SCH-WM case. In second frequency band $(50-70 \mathrm{~Hz})$ differences between energy indexes are still substantial when compare $\mathrm{HC}$ with $\mathrm{SCH}+\mathrm{WM}$ but when compare $\mathrm{SCH}+\mathrm{WM}$ and SCH-WM differences are higher than in first analyzed range. For last frequency range energy values were still highest for $\mathrm{SCH}+\mathrm{WM}$ and are close to values obtained for $\mathrm{HC}$ but in compare to SCH-WM differences are still very high.

Summarizing the MP results it can be seen that $\mathrm{SCH}+\mathrm{WM}$ have highest energy values in every frequency band in compare to other subjects. Also HC subject in every frequency range have higher energy indexes than SCH-WM. Values for SCH-WM can suggest that fast brain waves of this subject have very low amplitude which can be connected with abnormalities in voltage generating mechanism. On the other hand high energy level for $\mathrm{SCH}+\mathrm{WM}$ may suggest that subject have problems with neuronal overload.

\section{Discussion}

Our results clearly show a substantial difference in brain activity of a patient with schizophrenia and comorbid white matter damage, and a patient with the same psychiatric diagnosis, but without perceptible in the MRI structural brain damage, and a healthy person. Applied computational methods allowing evaluation of various gamma bands synchronization and power properties revealed abnormal hypersynchronization of gamma oscillations and marked increase in indicators of power. Coherence indexes of healthy participant, as well as $\mathrm{SCH}$ WM patient are internally varied, whereas all the coherence parameters, including both the inter- and intrahemispheric pairs of SCH + WM patients are very high, and over $30-100 \mathrm{~Hz}$ frequencies maintain rate higher than 0.80. It is also possible to observe, that the higher the frequency of the gamma bands, the higher are all tested parameters of brain bioelectric activity. Given the data discussed earlier, such extreme form of fast oscillations hyperactivity indicates the imbalance between basic bioelectric and biochemical processes of excitation and inhibition, leading to a profound disturbance of neuronal homeostasis.

Significant increase in the ratios of coherence in the gamma frequency has been described in several specific cases. For example, it was observed in individuals with pharmacologically induced acute psychotic euphoric-like experiences, for example, after taking ayahuasca; an entheogenic brew made out of Banisteriopsis caapi vine and the Psychotria viridis leaf [20]. Analogous abnormal increase in coherence and power was recorded as a result of experimentally-induced rapid hypoxia preceded by the heart arrest in rats [21]. Generally, although a few publications discuss gamma hypersynchronization determi- nants, its arises from abnormalities of brain function, which can be induced pharmacologically, may be associated with a disturbed neuronal activity in the inter-ictal periods [22] or damage to these structures and tissues which are part of the nervous system, causing pathological summation of the electrical activity in the form of overloading the surface of the cortex.

At least two possible mechanisms of excessive high frequencies activity occurrence comorbid with brain dysfunction or damage was found in the literature. In Buzsáki and Silva [23] proposal, based on the model of the buffering processes regulating synchronization of neural assemblies to prevent the occurrence of periods of pathological hyper- and hypo-synchronization, it is assumed that the various forms of brain injury lead to regulatory mechanisms breakdown. As a consequence, "in the case of impaired inhibitory control, recruitment of pyramidal neurons occurs much faster and may involve excess number of neurons. These patterns reflect an 'exaggerated' version of physiological activity." [23]. Another explanation can be presented by referring to the functional importance of myelin for precision of neural networks and assemblies operation, as discussed by Prajevic et al [24]. It indicates a key role of the conduction velocity (CV) parameters, which are closely related to both the axons diameter, but above all the physiological features of myelin, which as it has been shown [25], is able to adopt the requirements of temporal organization and synchronization of neural networks, and provides mediation of proper spike-time arrival among axons of various lengths, what enables converging of electric signals onto a common target. Temporal differentiation regarding delivery of action potentials is necessary to ensure proper conduction delays, without which it is impossible that the signals coming from distant brain structures through the axons and axonal clusters with different parameters (e.g. thickness) reached a particular neural goal at the same time, what is essential for neuronal activity, characterized by the mechanism of saltatory conduction. The significance of these properties may be depicted by the fact, that "at the small scale of neuronal cells, precise arrival of action potentials at the postsynaptic neuron is perhaps the most important factor in triggering a new action potential, since different spikes arriving only a few milliseconds apart will fail to integrate to cause sufficient depolarization" [24]. Furthermore the authors show that conduction delays smaller than $1 \mathrm{~ms}$ could affect the phase by $30^{\circ}$, substantially changing signal amplitude, and what could be of special importance regarding results obtained in our study, pathological distortions of a conduction delay on scale of $5 \mathrm{~ms}$ could turn interactions of several synchronized oscillators at the upper end of the gamma band in a form of destructive interference. Given the anatomical 
changes within the white matter in our patient, which extend far beyond the irregularities on the microstructural level, it can be assumed that the obtained data describing the neuronal activity, with pathological gamma frequency enhancement, might be significantly related to serious disturbances of biochemical and temporal mechanisms supporting balance between excitatory and inhibitory processes.

The data we collected and proposals of its explain show the complexity of the relationship between the electrochemical activity of the brain and white matter damage, which, according to current theoretical models is beginning to be recognized as an important neurophysiological structure involved in the regulation of human cognition and behavior.

\section{References:}

1. Uhlhaas P. J., Singer W. Neural synchrony in brain disorders: relevance for cognitive dysfunctions and pathophysiology. Neuron, 2006; 52, 155-16810.

2. Jia X, Kohn A. Gamma Rhythms in the Brain. PLoS Biol, 2011; 9(4): e1001045.

3. Başar, E. Brain oscillations in neuropsychiatric disease. Dialogues in Clinical Neuroscience, 2013; 15(3), 291-300.

4. Cardin JA, Carlén M, Meletis K, Knoblich U, Zhang F, et al. Driving fast-spiking cells induces gamma rhythm and controls sensory responses. Nature. 2009; 459:663-67.

5. Hirano Y., Oribe N., Kanba S., Onitsuka T., Nestor, P. G., \& Spencer, K. M. Spontaneous Gamma Activity in Schizophrenia. JAMA Psychiatry, 2015; 72(8), 813-821.

6. Messias, E., Chen, C.-Y., \& Eaton, W. W. Epidemiology of Schizophrenia: Review of Findings and Myths. The Psychiatric Clinics of North America, 2007; 30(3), 323-338.

7. Jonathan K. Wynn, Gregory A. Light, Bruno Breitmeyer, Keith H. Nuechterlein, and Michael F. Green. Event-Related Gamma Activity in Schizophrenia Patients During a Visual Backward-Masking Task. American Journal of Psychiatry, 2005; 162(12), 2330-2336.

8. Wilson T.W., Hernandez O.O., Asherin R.M., et al. Cortical gamma generators suggest abnormal auditory circuitry in early-onset psychosis. Cereb Cortex, 2008; 18, 371-378.

9. Williams LM, Whitford TJ, Gordon E, et al. Neural synchrony in patients with a first episode of schizophrenia: tracking relations with grey matter and symptom profile. J Psychiatry Neuroscience, 2009; 34, 21-29.

10. Cho R.Y., Konecky R.O., Carter C.S. Impairments in frontal cortical gamma synchrony and cognitive control in schizophrenia. Proc Natl Acad Sci U.S.A. 2006; 103(198), 78-83.

11. Minzenberg M. J., Firl A. J., Yoon J. H., Gomes G. C., Reinking C., \& Carter C. S. Gamma Oscillatory Power is Impaired During Cognitive Control Independent of Medication Status in First-Episode Schizophrenia. Neuropsychopharmacology, 2010; 35(13), 2590-2599.

12. Spencer K.M., Niznikiewicz M.A., Shenton M.E., et al. Sensoryevoked gamma oscillations in chronic schizophrenia. Biological Psychiatry, 2008;63:744-747.
13. Tikka S.K., Nizamie SH, Das B, Katshu MZ, Goyal N. Increased spontaneous gamma power and synchrony in schizophrenia patients having higher minor physical anomalies. Psychiatry Res. 2013; 207(3):164-72.

14. Mitra, S., Nizamie, S. H., Goyal, N. and Tikka S. K. Evaluation of resting state gamma power as a response marker in schizophrenia. Psychiatry Journal of Clinical Neuroscience, 2015; 69: 630-639.

15. Williams A. B.; Taylors F. J. Electronic Filter Design Handbook. New York McGraw-Hill 1988.

16. Kam J. W. Y., Bolbecker A. R., O’Donnell B. F., Hetrick W. P., Brenner C. A. Resting state EEG power and coherence abnormalities in bipolar disorder and schizophrenia. Journal of Psychiatric Research, 2013: 47(12), 1893-1901.

17. Stoica P., Moses R. Spectral Analysis of Signals. Upper Saddle River, NJ: Prentice Hall, 2005

18. Mallat S. G., Zhang Z. Matching Pursuit with time-frequency dictionaries. IEEE Transactions On Signal Processing,1993; 41(12), 3397-3415.

19. Franaszczuk P. J, Bergey G. K., Durka P. J., Eisenberg H. M. Timefrequency analysis using the matching pursuit algorithm to seizures originating from mesial temporal lobe. Electroencephalography and Clinical Neurophysiology, 1998; 106(6), 513-521.

20. Stuckey D.E., Lawson R., Luna L.E. EEG gamma coherence and other correlates of subjective reports during ayahuasca experiences. J Psychoactive Drugs.2005; 37(2):163-78.

21. Borjigin J., Lee U., Liu T., Pal D., Huff S., Klarr D., Mashour G. A. Surge of neurophysiological coherence and connectivity in the dying brain. Proceedings of the National Academy of Sciences of the United States of America, 2013; 110(35): 14432-14437.

22. Medvedev A. V., Murro A. M., Meador K. J. Abnormal interictal gamma activity may manifest a seizure onset zone in temporal lobe epilepsy. International Journal of Neural Systems, 2011; 21:02:103-114.

23. Buzsáki G, da Silva F.L. High frequency oscillations in the intact brain. Prog Neurobiol. 2012; 98:241-249.

24. Pajevic S., Basser P. J., \& Fields R. D. Role of Myelin Plasticity in Oscillations and Synchrony of Neuronal Activity. Neuroscience, 2014; 276, 135-147.

25. Liu I., Dietz K., DeLoyht J. M., Pedre X., Kelkar D., Kaur I., et al. Impaired adult myelination in the prefrontal cortex of socially isolated mice. Nature Neuroscience, 2012; 15, 1621-1624.

\section{Correspondence address}

Kamil Jonak

Instytut Technologicznych Systemów Informacyjnych

Politechnika Lubelska

Nadbystrzycka 36, 20-618 Lublin

k.jonak@pollub.pl

Otrzymano: 13.09.2016

Zrecenzowano: 21.09.2016

Przyjęto do druku: 21.09.2016 